University of Nebraska - Lincoln

DigitalCommons@University of Nebraska - Lincoln

Agronomy \& Horticulture -- Faculty Publications

Agronomy and Horticulture Department

$5-1990$

\title{
Registration of NP29, A Low-Dhurrin Sudangrass Population Selected for Tolerance to Early Spring Seeding
}

Francis A. Haskins

University of Nebraska-Lincoln, fhaskins@neb.rr.com

Herman J. Gorz

United States Department of Agriculture

K. P. Vogel

United States Department of Agriculture, kvogel1@unl.edu

Follow this and additional works at: https://digitalcommons.unl.edu/agronomyfacpub

Part of the Plant Sciences Commons

Haskins, Francis A.; Gorz, Herman J.; and Vogel, K. P., "Registration of NP29, A Low-Dhurrin Sudangrass Population Selected for Tolerance to Early Spring Seeding" (1990). Agronomy \& Horticulture -- Faculty Publications. 236.

https://digitalcommons.unl.edu/agronomyfacpub/236

This Article is brought to you for free and open access by the Agronomy and Horticulture Department at DigitalCommons@University of Nebraska - Lincoln. It has been accepted for inclusion in Agronomy \& Horticulture -Faculty Publications by an authorized administrator of DigitalCommons@University of Nebraska - Lincoln. 
from 1-wk-old seedlings grown in the same test resulted in the following values for means and standard errors $\left(\mathrm{mg} \mathrm{kg}^{-1}\right.$ fresh weight, bulk of 10 seedlings per replication, three replications): NP29 fertile bulk-202 \pm 11 ; NP29 male-sterile bulk-247 \pm 19 ; NP25 fertile bulk-181 \pm 11 ; NP25 malesterile bulk-228 \pm 26 ; 'Piper'-325 \pm 12 ; and 'Greenleaf'$567 \pm 32$.

Seed will be maintained and distributed by the Department of Agronomy, University of Nebraska, Lincoln, NE 68583. Germplasm amounts will be provided without cost to each applicant upon written request while supplies last. Two different types of NP29 are available for distribution: (i) bulked seed harvested from genetic male-sterile plants (GP-237), and (ii) bulked seed harvested from fertile plants. Recipients of the seed are asked to make appropriate recognition of the source of the germplasm if it is used in the development of a new germplasm, parental line, cultivar, or hybrid.

\section{F. A. Haskins, ${ }^{*}$ H. J. GoRz, aNd K. P. Vogel (5)}

\section{References and Notes}

1. Gorz, H.J., W.L. Haag, J.E. Specht, and F.A. Haskins. 1977. Assay of phydroxybenzaldehyde as a measure of hydrocyanic acid potential in sorghums. Crop Sci. 17:578-582.

2. Gorz, H.J., F.A. Haskins, and K.P. Vogel. 1986. Registration of NP23 and NP24 sudangrass germplasms. Crop Sci. 26:212-213.

3. Haskins, F.A., H.J. Gorz, S.D. Kindler, S.G. Jensen, and A. SotomayorRios. 1986. Registration of NP25 low-dhurrin sudangrass germplasm. Crop Sci. 26:213.

4. Haskins, F.A., H.J. Gorz, and K.P. Vogel. 1990. Registration of NP31 and NP32, two populations of sudangrass selected for low-dhurrin content. Crop Sci. 30:759-760.

5. H.J. Gorz (retired) and K.P. Vogel, USDA-ARS; and F.A. Haskins (retired), Dep. of Agronomy, University of Nebraska, Lincoln, NE 68583 Cooperative investigations of USDA-ARS and the Nebraska Agric. Res. Division. Published as Journal Series Paper no. 8934, Nebraska Agric. Res. Division. Registration by CSSA. Accepted 31 Aug. 1989. *Corresponding author.

Published in Crop Sci. 30:758-759 (1990). 